\title{
Combined nanoimprint and photolithography of integrated polymer optics
}

\author{
Christiansen, Mads Brøkner; Schøler, Mikkel; Gersborg-Hansen, Morten; Kristensen, Anders
}

Published in:

Digest of the IEEE LEOS Summer Topical Meetings, 2007

Link to article, DOI:

10.1109/LEOSST.2007.4288352

Publication date:

2007

Document Version

Publisher's PDF, also known as Version of record

Link back to DTU Orbit

Citation (APA):

Christiansen, M. B., Schøler, M., Gersborg-Hansen, M., \& Kristensen, A. (2007). Combined nanoimprint and photolithography of integrated polymer optics. In Digest of the IEEE LEOS Summer Topical Meetings, 2007 (pp. 101-102). [4288352] IEEE. https://doi.org/10.1109/LEOSST.2007.4288352

\section{General rights}

Copyright and moral rights for the publications made accessible in the public portal are retained by the authors and/or other copyright owners and it is a condition of accessing publications that users recognise and abide by the legal requirements associated with these rights.

- Users may download and print one copy of any publication from the public portal for the purpose of private study or research.

- You may not further distribute the material or use it for any profit-making activity or commercial gain

- You may freely distribute the URL identifying the publication in the public portal 


\title{
Combined nanoimprint and photolithography of integrated polymer optics
}

\author{
Mads Brøkner-Christiansen, Mikkel Schøler, Morten Gersborg-Hansen, and Anders Kristensen* \\ MIC - Department of Micro and Nanotechnology, Nano $\bullet$ DTU, Technical University of Denmark, \\ DTU building 345east, DK-2800 Kongens Lyngby, Denmark \\ *e-mail:ak@mic.dtu.dk_www.mic.dtu.dk/NIL
}

We demonstrate wafer-scale fabrication by combined nanoimprint and photolithography (CNP) [1] of integrated polymer optics, combining active and passive polymer components with $\mathrm{nm}$ to $\mathrm{mm}$ features. Distributed feed-back (DFB) polymer dye lasers [2] are integrated with polymer waveguides [3]. The laser devices are defined in SU-8 resist, doped with Rhodamine 6G laser dye, shaped as planar slab waveguides on a Fused Silica buffer substrate, and with a $1^{\text {st }}$-order DFB surface corrugation forming the laser resonator, see Fig. 1. When optically pumped at $532 \mathrm{~nm}$, lasing is obtained in the wavelength range $560 \mathrm{~nm}-600 \mathrm{~nm}$, determined by the grating period, see Fig. 3. Our results, where 20 laser devices are defined across a $10 \mathrm{~cm}$ diameter wafer substrate, demonstrate the feasibility of CNP for wafer-scale fabrication of advanced nanostructured active and passive polymer optical components
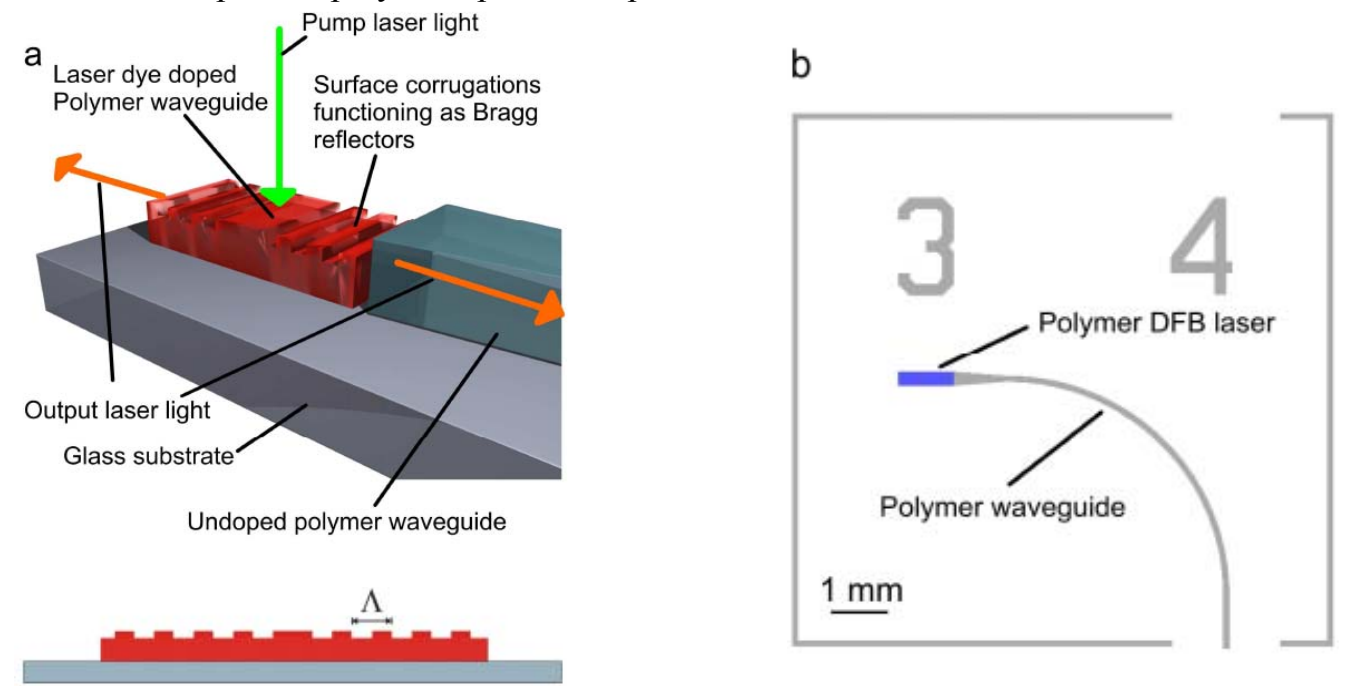

Fig. 1 (a): Outline of the distributed feed-back (DFB) polymer dye laser device, formed as a slab waveguide on a borofloat glass substrate. Feedback is provided by Bragg grating surface corrugations of period $\Lambda \sim 200$ nm. (c) The chip layout. The laser is positioned $10 \mu \mathrm{m}$ from a curved waveguide made of $4.2 \mu \mathrm{m}$ thick undoped SU-8 polymer. 20 chips are defined across the $10 \mathrm{~cm}$ diameter wafer substrate.

In the CNP process, a combined UV mask and nanoimprint stamp, Fig 2 (a)-(b), is embossed into the resist, which is softened by heating, and UV exposed, Fig 2 (c)-(d). Hereby the $\mathrm{mm}$ to $\mu \mathrm{m}$ sized features are defined by the UV exposure through the metal mask, while nm-scale features are formed by mechanical deformation (nanoimprinting). The UV exposed (and imprinted) SU-8 is crosslinked by a post-exposure bake, before the stamp and substrate are separated, and the un-exposed resist is dissolved, Fig. 2 (e). Polymer waveguides are added [3] by an additional UV lithography step in a film of un-doped SU-8, which is spincoated on top of the lasers and substrate, Fig. 2 (f)-(g).

The combined UV mask and nanoimprint stamp is fabricated from a $10 \mathrm{~cm}$ diameter, $500 \mu \mathrm{m}$ thick Quartz wafer. To define the sub-micron features $(\Lambda \sim 200 \mathrm{~nm}$ period Bragg gratings), the Quartz wafer is spincoated with a $50 \mathrm{~nm}$ thick film of TEBN-1 electron beam lithography (EBL) resist, and a $20 \mathrm{~nm}$ aluminium film is deposited to avoid charging effects during the EBL exposure. Following the $100 \mathrm{kV}$ EBL exposure, the charge compensating layer is removed in MF-322 and the TEBN-1 resist is developed in methyl isobutyl ketone (MIBK). A RIE process transfers the gratings $40 \mathrm{~nm}$ into the substrate. The UVL mask - $200 \mathrm{~nm} \mathrm{Cr}$ 
and $20 \mathrm{~nm}$ aluminium - is defined by UV lithography and lift-off. Before metal deposition, the un-masked areas are recess-etched by RIE $(250 \mathrm{~nm})$. Finally, an anti-stiction coating is deposited on the stamp. The Rhodamine 6G perchlorate doped SU-8 resist (13 wt\% solid content SU-8 in cyclopentanone) is prepared as described in [3]. The final Rhodamine concentration is $3.2 \mu \mathrm{mol}$ per g solid SU-8. The SU-8 is spincoated onto a borofloat glass substrate to a thickness of $450 \mathrm{~nm}$. The combined UV mask and stamp is embossed into the unexposed SU-8 at $90^{\circ} \mathrm{C}$ and 2.5 bar before UV (i-line) exposure, and post-bake $\left(2 \mathrm{~min} .90^{\circ} \mathrm{C}\right)$. After separation the SU-8 is developed in PGMEA.

(a)

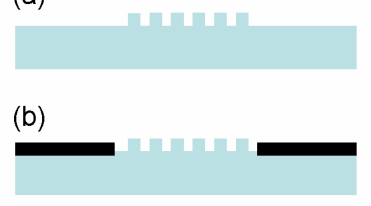

(c)

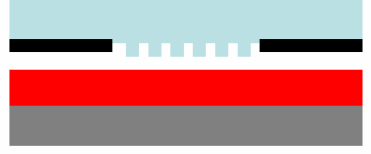

(d)

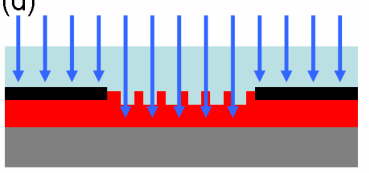

(e)

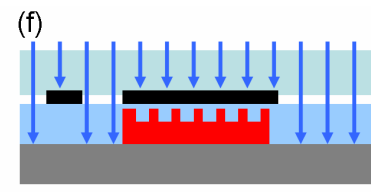

(g)

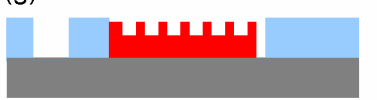

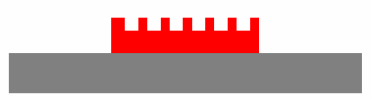

Fig. 2 Outline of the CNP fabrication process. (a)-(b): Combined UV mask and imprint stamp is used. (c)-(e): Embossing and UV exposure of dye doped resist to form DFB lasers. (f)-(g) Additional UV lithography step in undoped SU-8 film to define polymer waveguides.

$\mathrm{a}$

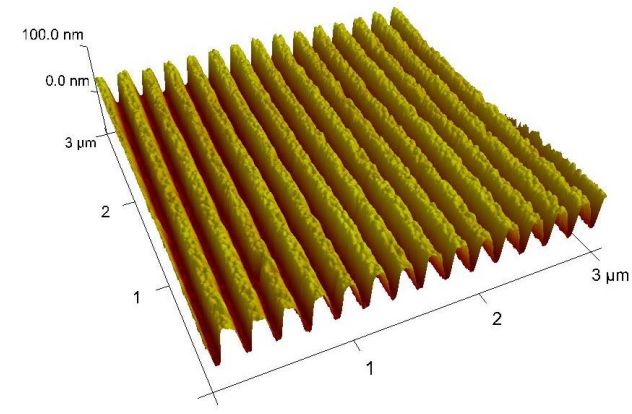

b

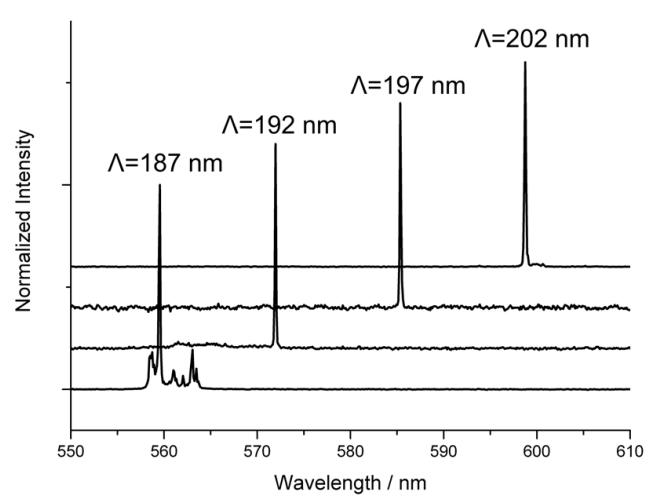

Fig. 3 (a) AFM image of a fabricated DFB surface corrugation. The period is $\Lambda=188 \mathrm{~nm}$, and the corrugation depth is $a=60 \mathrm{~nm}$. (b) Emission spectra from four laser devices of different DFB grating pitch.

Fig. 3a shows an AFM image of a CNP fabricated surface corrugation, forming the Bragg gratings. The period is $\Lambda=188 \mathrm{~nm}$. This grating is expected to yield $1^{\text {st }}$ order Bragg reflection at a vacuum wavelength of $577 \mathrm{~nm}$. In Fig. $3 \mathrm{~b}$ we show the emission spectra from four lasers of different DFB grating periond $\Lambda$.

\section{References:}

[1] X. Chen and L. Jay Guo, "One-step lithography for various size patterns with a hybrid mask-mold”, Microelectron. Eng. 71, 288 (2004)

[2] S. Balslev, T. Rasmussen, P.Shi, and A. Kristensen, "Single mode solid state distributed feedback dye laser fabricated by grey scale electron beam lithography on dye doped SU-8 resist", J. Micromech. Microeng., Vol. 15, 2456 (2005)

[3] D. Nilsson, S. Balslev, M. M. Gregersen, and A. Kristensen, "Micro-fabricated solid state dye lasers based on a photodefinable polymer", Applied Optics, Vol. 44, 4965 (2005) 